\title{
Evaluation of the Antibacterial Effects of Single and Combined use of Different Irrigation Solutions Against Intracanal
} Enterococcus Faecalis

\section{Prosudba antibakterijskog učinka pojedinačne i kombinirane uporabe otopina za ispiranje korijenskih kanala na Enterococcus faecalis}

\footnotetext{
${ }^{1}$ Department of Endodontics, Faculty of Dentistry, Alanya Alaaddin Keykubat University, Alanya, Antalya, Turkey Katedra za endodonciju Stomatološkog fakulteta Sveučilišta Alanya Alaaddin Keykubat

2 Department of Endodontics, Faculty of Dentistry, Selcuk University, Konya, Turkey Katedra za endodonciju Stomatološkog fakulteta Sveučilišta Selcuk, Konja, Turska ${ }^{3}$ Department of Microbiology, Faculty of Veterinary Medicine, Selcuk University, Konya, Turkey Katedra za mikrobiologiju Veterinarskog fakulteta Sveučilišta Selcuk, Konja, Turska

${ }^{4}$ Department of Preventive and Restorative Sciences, School of Dental Medicine University of Pennsylvania, Philadelphia, Pennsylvania Katedra za preventivne i restaurativne znanosti Medicinskog fakulteta Sveučilišta Pennsylvania, Philadelphia, SAD
}

\section{Abstract}

Objectives: This study assessed the antibacterial activity of both separate and combined uses of $5.25 \%$ sodium hypochlorite $(\mathrm{NaOCl}), 2 \%$ chlorhexidine (CHX), $17 \%$ ethylenediaminetetraacetic acid (EDTA), 3\% hydrogen peroxide $\left(\mathrm{H}_{2} \mathrm{O}_{2}\right)$, MTAD, SmearClear (SC) and $13.8 \%$ chlorine dioxide $\left(\mathrm{ClO}_{2}\right)$ irrigation solutions against Enterococcus faecalis. Material and Methods: Two hundred eighty single rooted human premolars were randomly grouped into 26 test and 2 control (negative and positive) groups and were incubated for $24 \mathrm{~h}$ with $E$. faecalis, except for the negative control group. The tested solutions were as follow: $\mathrm{NaOCl}$; $\mathrm{CHX} ; \mathrm{ClO}_{2}$; MTAD; SC; EDTA; $\mathrm{H}_{2} \mathrm{O}_{2} ; \mathrm{NaOCl}+\mathrm{CHX} ; \mathrm{NaOCl}+\mathrm{MTAD} ; \mathrm{SC}$ + NaOCl; EDTA + NaOCl; $\mathrm{H}_{2} \mathrm{O}_{2}+\mathrm{NaOCl} ; \mathrm{ClO}_{2}+\mathrm{CHX} ; \mathrm{CHX}+\mathrm{MTAD} ; \mathrm{SC}+\mathrm{CHX} ; \mathrm{EDTA}+\mathrm{CHX} ; \mathrm{CHX}+\mathrm{H}_{2} \mathrm{O}_{2}$; $\mathrm{ClO}_{2}+\mathrm{MTAD} ; \mathrm{SC}+\mathrm{ClO}_{2} ;$ EDTA $+\mathrm{ClO}_{2} ; \mathrm{ClO}_{2+} \mathrm{H}_{2} \mathrm{O}_{2} ; \mathrm{SC}+\mathrm{MTAD} ; \mathrm{EDTA}+\mathrm{MTAD} ; \mathrm{MTAD}+\mathrm{H}_{2} \mathrm{O}_{2} ; \mathrm{SC}+\mathrm{H}_{2} \mathrm{O}_{2} ;$ and $\mathrm{EDTA}+\mathrm{H}_{2} \mathrm{O}_{2}$ Optic density values were recorded at $0,6,12,18,24,30,36,42$ and $48 \mathrm{~h}$ and bacterial growth curve created for each solution. Results: The CHX, MTAD and $\mathrm{ClO}_{2}$ showed a high potential for the elimination of $E$. faecalis, both alone and in all combinations. The EDTA, $\mathrm{H}_{2} \mathrm{O}_{2}, \mathrm{H}_{2} \mathrm{O}_{2}+$ EDTA, $\mathrm{H}_{2} \mathrm{O}_{2}+\mathrm{NaOCl}$ and $\mathrm{SC}+\mathrm{NaOCl}$ groups showed less antibacterial activity than the other groups. The $\mathrm{SC}$ $+\mathrm{CHX}$ group showed the best antibacterial effect against $E$. faecalis. Conclusion: The $\mathrm{SC}+\mathrm{CHX}$ combination can be recommended as the most effective irrigation regimen against $E$. faecalis in persistent endodontic infections.
Received: May 20, 2020

Accepted: August 11, 2020

Address for correspondence Hatice Buyukozer Ozkan Alanya Alaaddin Keykubat University, Faculty of Dentistry Department of Endodontics Konaklı Mah. Mustafa Kemal Blv. No: 82 Alanya/Antalya 07400, TURKEY Tel: +905309710252

E mail: hatice.ozkan@alanya.edu.tr hatice.buyukozer@gmail.com

Key words

Root Canal Irrigants; Local Anti-Infective Agents; E. faecalis

\section{Introduction}

Microorganisms are one of the significant etiological factors in the pathogenesis of periapical tissue diseases. For this reason, it is very important to completely remove microorganisms from the infected root canals during a root canal treatment. Some ex vivo and clinical studies have reported that there are some untouched areas in the root canal walls during mechanical preparation. Therefore, to combine mechanical instrumentation with chemical irrigation is extremely important $(1,2,3)$ in elimination of the microorganisms known to be extremely resistant against antimicrobial agents, such as Enterococcus (E.) faecalis (4).

The relationship of $E$. faecalis with different forms of periradicular infections, including primary and permanent infec-
Uvod

Mikroorganizmi su jedan od važnijih etioloških čimbenika u patogenezi bolesti periapikalnog tkiva. To je razlog da je tijekom endodontskog liječenja vrlo važno potpuno ukloniti mikroorganizme iz zaraženih korijenskih kanala. U nekim istraživanjima ex vivo i kliničkim studijama autori su pokazali da postoje mnoga nedirnuta područja na stijenkama korijenskog kanala tijekom mehaničke pripreme. Zato je kombiniranje mehaničkih instrumenata s kemijskom irigacijom itekako važno $(1,2,3)$ u uklanjanju mikroorganizama za koje se zna da su iznimno otporni na antimikrobna sredstva, kao što je Enterococcus (E.) faecalis (4).

Odnos bakterije $E$. faecalis s različitim oblicima periradikularnih infekcija, uključujući primarne i kronične infekcije, 
tions, is well known because of its ability to grow in the presence or absence of oxygen. E. faecalis has been reported to be associated more with asymptomatic chronic periradicular lesions rather than acute periradicular periodontitis or acute periradicular abscesses in the category of primary endodontic infections $(5,6)$. It has been confirmed that $E$. faecalis is significantly associated with treatment failures. Whereas this species was detected in $18 \%$ of the cases of primary endodontic infections, its prevalence in root-filled teeth was much higher: $67 \%$ of the cases (7).

Different endodontic irrigation solutions and disinfection techniques have been introduced to decrease the root canal bacterial count. The main effect of irrigation is to both physically and chemically remove organic and inorganic debris, infected materials and soft and hard tissue residues from the root canals. In this way, these materials are inhibited from accumulating, clogging and becoming inaccessible in the apical section of the root canals. Endodontic irrigation solutions usually have antibacterial properties. It has been proven that a combined use of irrigation materials with a different antimicrobial spectrum can even increase the antibacterial activity provided by a single solution through a synergic and/or additive effect for the elimination of hundreds of types of microorganisms forming on the root canal microflora (5).

There is a limited number of studies in the literature assessing and comparing the combined use of frequently used endodontic irrigation solutions in terms of their antibacterial characteristics. The positive or negative effects of the antibacterial interactions of current and potential irrigation solutions will especially guide the treatment of persistent endodontic infections. Therefore, understanding the interactions between irrigation solutions will be very helpful in implementing the most effective treatment procedure for persisting infections in endodontic cases. This current study aimed to investigate the antibacterial activity of both the single and combined uses of sodium hypochlorite $(\mathrm{NaOCl})$, chlorhexidine (CHX), ethylenediaminetetraacetic acid (EDTA), hydrogen peroxide $\left(\mathrm{H}_{2} \mathrm{O}_{2}\right)$ BioPure MTAD (Densply, Tulsa Dental, Tulsa, OK, USA). SmearClear (SC) (Sybron Endo, Orange, CA, USA) and chlorine dioxide $\left(\mathrm{ClO}_{2}\right)$ against $E$. faecalis and to compare the antibacterial effects of this study's solutions against $E$. faecalis.

\section{Material and Methods}

The current study was started after receiving approval from the Ethical Board of Selcuk University, Faculty of Dentistry (Document \# 203). One hundred eighty single-rooted human lower premolars that had been extracted for orthodontic or periodontal reasons were used. The hard and soft tissue residuals on the teeth were cleaned with curettes and then the teeth were kept at $4^{\circ} \mathrm{C}$ in a $100 \%$ moist environment until the laboratory procedures were performed.

The teeth were de-coronated with a diamond disk (Ortho Technology Inc., Tampa, FL, USA) under water cooling to a standardized root length of $14 \pm 0.5 \mathrm{~mm}$. The canal lengths were standardized with $15 \mathrm{~K}$-File hand devices (Mani Inc., Tochigi, Japan) and enlarged with ProTaper Universal NiTi dobro je poznat zbog njegova svojstva rasta kako u prisutnosti kisika, tako i u njegovoj odsutnosti. Za E. faecalis dokazano je da je više povezan $s$ asimptomatskim kroničnim periradikularnim lezijama, a ne s akutnim periradikularnim parodontitisom ili akutnim periradikularnim apscesima u kategoriji primarnih endodontskih infekcija $(5,6)$. Potvrđeno je da je ta bakterija značajno povezana s neuspjehom liječenja. Iako je ta vrsta otkrivena u $18 \%$ slučajeva primarnih endodontskih infekcija, njezina prevalencija u endodontski liječenim zubima bila je mnogo veća - $67 \%$ slučajeva (7).

Predstavljene su različite otopine za endodontsku irigaciju i tehnike dezinfekcije kako bi se smanjio broj bakterija u korijenskim kanalima. Glavni učinak irigacije jest fizičko i kemijsko uklanjanje organskih i anorganskih nečistoća, zaraženih materijala i ostataka mekoga i tvrdoga tkiva iz korijenskih kanala. Na taj se način sprječava nakupljanje i začepljenje tim materijalima koji onemogućuju pristup apikalnom dijelu korijenskih kanala. Otopine za endodontsku irigaciju obično imaju antibakterijska svojstva. Dokazano je da kombinirana upotreba otopina za irigaciju različitoga antimikrobnog spektra može čak povećati antibakterijsko djelovanje koje ima pojedinačna otopina sinergijskim i/ili dodatnim učinkom za uklanjanje stotina vrsta mikroorganizama koji se formiraju u mikroflori korijenskog kanala (5).

Pregledom dosadašnje literature ustanovljen je ograničen broj studija u kojima se procjenjuje i uspoređuje kombinirana upotreba često korištenih endodontskih otopina za irigaciju, kad je riječ o njihovim antibakterijskim svojstvima. Pozitivni ili negativni učinci antibakterijskih interakcija postojećih i potencijalnih otopina za irigaciju posebno će usmjeravati liječenje perzistentnih endodontskih infekcija. Zato će razumijevanje interakcije između otopina za irigaciju biti od velike pomoći u provedbi najučinkovitijeg postupka liječenja perzistentnih infekcija u endodontskim slučajevima. Ova studija imala je za cilj istražiti antibakterijsko djelovanje pojedinačnih i kombiniranih primjena natrijeva hipoklorita $(\mathrm{NaOCl})$, klorheksidina (CHX), etilendiamintetraoctene kiseline (EDTA), vodikova peroksida $\left(\mathrm{H}_{2} \mathrm{O}_{2}\right)$, BioPure, MTAD-a (Densply, Tulsa Dental, Tulsa, OK, SAD), SmearCleara (SC) (Sybron Endo, Orange, CA, SAD) i klorova dioksida $\left(\mathrm{ClO}_{2}\right)$ na E. faecalis i usporediti antibakterijske učinke svih korištenih otopina u studiji.

\section{Materijali i metode}

Ovo istraživanje započeto je nakon što ga je odobrilo Etičko povjerenstvo Stomatološkog fakulteta Sveučilišta Selcuk (dokument br. 203). Korišteno je stotinu i osamdeset jednokorijenskih ljudskih donjih pretkutnjaka (premolara) izvađenih iz ortodontskih ili parodontskih razloga. Ostatci tvrdoga i mekoga tkiva na zubima očišceni su kiretama, a zatim su do laboratorijskih postupaka zubi čuvani na temperaturi od $4{ }^{\circ} \mathrm{C} \mathrm{u} 100 \%$ vlažnom okružju.

Zubi su dekoronirani dijamantnim diskom (Ortho Technology Inc., Tampa, FL, SAD) uz vodeno hlađenje do standardizirane dužine korijena od $14 \pm 0,5 \mathrm{~mm}$. Dužine kanala standardizirane su ručnim instrumentom K-File \#15(Mani Inc., Tochigi, Japan) i proširene su ProTaper univerzal- 
rotary files (Dentsply, Tulsa Endodontics, Tulsa, OK, USA) using the crown-down method. The apical parts of the root canals were finished at F3. During the preparations, the root canals were irrigated with $1 \mathrm{ml}$ of $5.25 \% \mathrm{NaOCl}$ solution (Caglayan Kimya San., Konya, Turkey).

In order to remove the smear layer of root canal walls, the roots were exposed to an ultrasonic bath (USG 4000 Ultraschall, Dentaurum, Ispringen, Germany) in 17 \% EDTA (AppliChem GmbH, Darmstadt, Germany), 5.25\% NaOCl and distilled water for $10 \mathrm{~min}$ in each solution, in that order (8). The samples were then embedded perpendicular to the long axes in a silicone impression material (Zetaplus, Zhermack SpA, Badia Polesine (RO), Italy) and placed in metal plates filled with distilled water and capped, 10 in each group, and sterilized at $121^{\circ} \mathrm{C}$ for $20 \mathrm{~min}$ in an autoclave (Hirayama, Saitama, Japan). The metal plates were then opened inside a Biosafety Level 2 (BSL 2) lamina air-flow cabin and each sample was coated with two layers of nail polish (Loreal Jet-Set Diamond, Paris, France) in order to prevent bacterial leak during the experimental procedures. In order to contaminate the sterilized root canals with $E$. faecalis for experimental purposes, fresh cultures of $E$. faecalis (ATCC 29212) microorganisms were obtained after $24 \mathrm{~h}$ of incubation inside Brain Heart Infusion Broth (BHI) (bioMerieux' sa 69280, Marcy I'Etoile, France). The optical density (OD) of the $E$. faecalis suspension inside BHI was adjusted according to McFarland No: 0.5 standard to approximately $1.5 \times 10^{8}$ colony/ $\mathrm{ml}$. Except for the negative control group, the E. faecalis suspension was planted to the root canals with the help of a sterile $1 \mathrm{ml}$ tuberculin syringe. Then, the samples in the metal plates were incubated at $37^{\circ} \mathrm{C}$ for $24 \mathrm{~h}$. After incubation, the metal plates were opened in a BSL 2 air-flow cabin and irrigation was performed with the experimental solutions.

A flow chart of the study design is shown in Figure 1. The basic irrigation solutions and their combinations used in the study are presented in Table 1 . All solutions except for EDTA were ready to use. The $17 \%$ EDTA solution was prepared in the laboratory according to the instructions of Sen et al. (9).

Each root canal was irrigated with a single or combined irrigation solution for $5 \mathrm{~min}$ using 30-gauge endodontic irrigation needles (KerrHawe SA, Bioggio, Switzerland), according to the irrigation regimens indicated in Figure 1. Sterile F3 paper cones were placed into the root canals for $1 \mathrm{~min}$ to allow for complete absorption. The paper cones were then put into sterile tubes containing $1 \mathrm{ml} \mathrm{BHI} \mathrm{Broth}$ and placed into a vortex device (MS 1 Minishaker IKA ${ }^{\oplus}$, Darmstadt, Ger- nim nikal-titanijskim rotacijskim instrumentima (Dentsply, Tulsa Endodontics, Tulsa, OK, SAD) primjenom tzv. metode crown-down. Obrada apikalnih dijelova korijenskih kanala završena je instrumentom F3. Tijekom preparacije, korijenski kanali irigirani su $1 \mathrm{~mL} \mathrm{5,25-postotne} \mathrm{otopine} \mathrm{natrijeva}$ hipoklorita (Caglayan Kimya San., Konja, Turska).

Kako bi se uklonio zaostatni sloj sa stijenki korijenskih kanala, korijeni su bili izloženi ultrazvučnoj kupki (USG 4000 Ultraschall, Dentaurum, Ispringen, Njemačka) u 17-postotnoj EDTA-i (AppliChem GmbH, Darmstadt, Njemačka), 5,25-postotnom natrijevu hipokloritu i destiliranoj vodi po 10 minuta u svakoj otopini, tim redoslijedom (8). Uzorci su zatim ugrađeni okomito na uzdužnu os u silikonski otisni materijal (Zetaplus, Zhermack SpA, Badia Polesine (RO), Italija) te stavljeni u metalne ploče napunjene destiliranom vodom i zatvorene, po 10 u svakoj skupini, i 20 minuta sterilizirane na $121^{\circ} \mathrm{C}$ u autoklavu (Hirayama, Saitama, Japan). Zatim su metalne ploče otvorene u kabini za laminaciju zraka na razini biološke sigurnosti (BSL 2) i svaki je uzorak premazan dvama slojevima laka za nokte (Loreal Jet-Set Diamond, Pariz, Francuska) da bi se spriječilo istjecanje bakterija tijekom pokusnog procesa. Kako bi se za pokusne svrhe kontaminirali sterilizirani korijenski kanali bakterijom $E$. faecalis, svježe kulture mikroorganizama E. faecalis (ATCC 29212) dobivene su nakon 24-satne inkubacije u juhi od moždane supstancije tj. medij Brain Heart Infusion Broth - BHI (bioMerieux sa 69280, Marcy I 'Etoile, Francuska). Optička gustoća (OG) suspenzije E. faecalis unutar BHI-ja podešena je u skladu s McFarlandovim No: 0,5 standardom do približno 1,5 x 108 kolonije/ $\mathrm{mL}$. Uz negativnu kontrolnu skupinu, suspenzija $E$. faecalis postavljena je u korijenske kanale s pomoću sterilne $1 \mathrm{~mL}$ tuberkulinske štrcaljke. Zatim su uzorci u metalnim pločama inkubirani 24 sata na temperaturi od $37^{\circ} \mathrm{C}$. Nakon inkubacije metalne ploče su otvorene u kabini s protokom zraka BSL $2 \mathrm{i}$ irigacija je obavljena s pokusnim otopinama.

Shema dijagrama dizajna studije prikazana je na slici 1. Osnovne otopine za irigaciju i njihove kombinacije korištene u studiji nalaze se u tablici 1. Sve otopine, osim EDTA-e, bile su spremne za upotrebu. 17-postotna otopina EDTA-e pripremljena je u laboratoriju prema uputama Sena i suradnika. (9).

Svaki je korijenski kanal irigiran jednom ili kombiniranom otopinom u trajanju od 5 minuta s pomoću endodontskih igala promjera 30 za vlaženje korijenskih kanala (KerrHawe SA, Bioggio, Švicarska) prema protokolima irigacije navedenima na slici 1 . Zatim su u korijenske kanale jednu minutu stavljeni sterilni papirnati štapići F3 da bi se omogu-

\begin{tabular}{|c|c|}
\hline The Basic Irrigation Solutions • Osnovne irigacijske otopine & Manufacturer $\bullet$ Proizvođač \\
\hline $5.25 \%$ Sodium hypochlorite $(\mathrm{NaOCl}) \bullet 5,25$-postotni natrijev hipoklorit $(\mathrm{NaOCl})$ & Caglayan Kimya San., Konya/Turkey• Turska \\
\hline 2 \% Chlorhexidine gluconate $(\mathrm{CHX}) \bullet 2$-postotni klorheksidin-glukonat (CHX) & Klorhex, Drogsan ilaç san., Ankara/Turkey• Turska \\
\hline $13.8 \%$ Chlorine dioxide $\left(\mathrm{ClO}_{2}\right) \cdot 13,8$-postotni klorni dioksid $\left(\mathrm{ClO}_{2}\right)$ & Bioclenz, Frontier Pharmaceutical, Melville, NY, USA • SAD \\
\hline BioPure MTAD (MTAD) & Dentsply, Tulsa Dental, Tulsa, OK, USA • SAD \\
\hline SmearClear (SC) & Sybron Endo, Orange, CA, USA • SAD \\
\hline $3 \%$ Hydrogen peroxide $\left(\mathrm{H}_{2} \mathrm{O}_{2}\right) \cdot 3$-postotni vodikov peroksid $\left(\mathrm{H}_{2} \mathrm{O}_{2}\right)$ & Kimpa ilaç lab. Ve tic. Ltd. sti.; Istanbul, Turkey • Turska \\
\hline $\begin{array}{l}17 \% \text { Ethylene Diamine Tetra Acetic Acid (EDTA) } \\
17 \text {-postotna etilendiamintetraoctena kiselina (EDTA) }\end{array}$ & Prepared in the laboratory $\bullet$ Pripremljeno u laboratoriju \\
\hline
\end{tabular}


Flow Chart of the Study Design

\begin{tabular}{|c|c|}
\hline \multicolumn{2}{|r|}{280 enlarged, smear layer removed human premolar teeth } \\
\hline \multirow{2}{*}{\multicolumn{2}{|c|}{$\begin{array}{l}\text { The teeth were embedded in silicone impression materials and sterilized in an autoclave at } 121^{\circ} \mathrm{C} \\
\text { and } 100 \% \text { humid for } 20 \mathrm{~min} .\end{array}$}} \\
\hline & \\
\hline \multicolumn{2}{|r|}{$\downarrow$} \\
\hline \multicolumn{2}{|c|}{ All root surfaces were coated with two layers of nail polish and placed back into silicone } \\
\hline$\downarrow$ & $\downarrow$ \\
\hline $\begin{array}{l}\mathrm{N}: 10 \\
\text { Negative Control } \\
5 \mathrm{ml} \text { Saline for } 5 \mathrm{~min} \text {. }\end{array}$ & $\begin{array}{l}\mathrm{N}: 270 \\
10 \mu \mathrm{l} \text { of E. faecalis suspension with a sterile } 1 \mathrm{ml} \text { tuberculin syringe were cultured and } \\
\text { incubated at } 37^{\circ} \mathrm{C} \text { for } 24 \mathrm{~h} \text {. }\end{array}$ \\
\hline 4 & $\nabla$ \\
\hline $\begin{array}{l}\mathrm{N}: 10 \\
\text { Positive Control } \\
5 \mathrm{ml} \text { Saline for } 5 \mathrm{~min} \text {. }\end{array}$ & 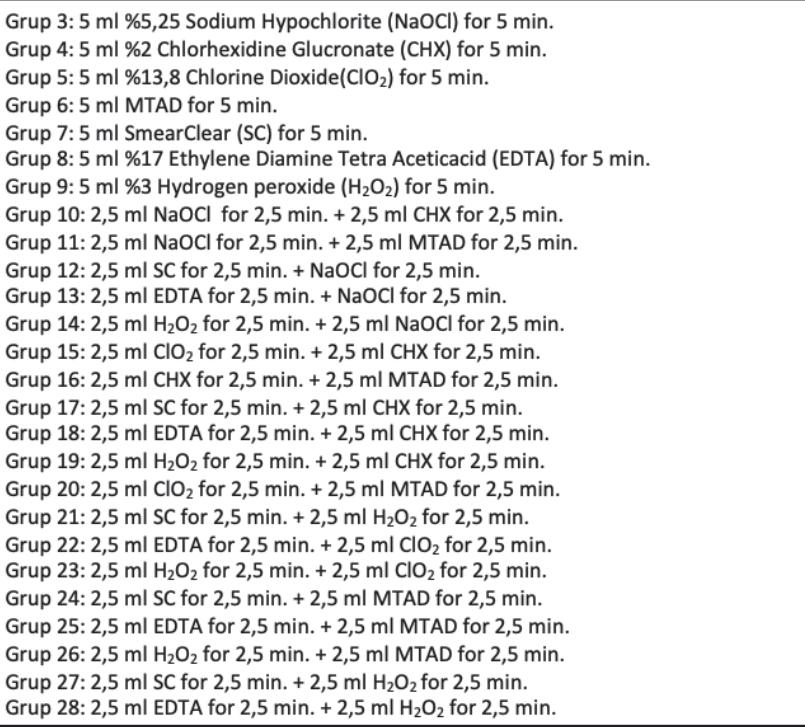 \\
\hline
\end{tabular}

Figure 1 Flow Chart of the Study Design Slika 1. Dijagram nacrta istraživanja many) for $5 \mathrm{~min}$. A $200 \mu \mathrm{l}$ sample was taken from the shaken medium and transferred to a well in a 96-well sterile ELISA plate (Costar 3599, Corning, NY, USA). Each sample went through this procedure twice for a total of two wells per sample to get averages for the measurements. The plates were then placed in an ELISA reader (BioTek ELx800, Absorbance Microplate Reader, Winooski, VT, USA) to complete the first optic density (OD) test (hour 0) at a wavelength of $450 \mathrm{~nm}$, and the data were recorded. The data were taken every $6 \mathrm{~h}$ in the ELISA reader and repeated twice. The plates were placed in the incubator and kept at $37^{\circ} \mathrm{C}$ in a 100 $\%$ moist environment during the experiment. Data were obtained for each sample at hours $0,6,12,18,24,30,36,42$ and 48 . The averages of the data collected at each measurement were calculated separately for each group, and an average OD value was determined for each period. Average OD data obtained for each sample at each time period were used, and a time-dependent OD change graph was created for each experimental group (Figure 2,4-10)

For statistical analysis, the Kruskal-Wallis and MannWhitney $U$ tests were used to find any significant differences among the study groups. Significance level was accepted as $\mathrm{p}>0.05$. ćila potpuna apsorpcija. Nakon toga su papirnati štapići odloženi u sterilne epruvete $s 1 \mathrm{~mL}$ medija BHI i stavljeni $5 \mathrm{mi}-$ nuta u vibrirajući uređaj (MS 1 Minishaker IKA ${ }^{\oplus}$, Darmstadt, Njemačka). Uzorak od $200 \mathrm{uL}$ uzet je iz protresenog medija i premješten u jažicu u sterilnoj ELISA ploči s 96 jažica (Costar 3599, Corning, NY, SAD). Svaki je uzorak dvaput prošao taj postupak za ukupno dvije jažice po uzorku da bi se dobili prosjeci za mjerenja. Ploče su zatim stavljene u čitač ELISA-e (BioTek EL x 800, čitač apsorpcijskih mikroploča, Winooski, VT, SAD) kako bi se završio prvi test optičke gustoće (OG) (sat 0) pri valnoj dužini od $450 \mathrm{~nm}$. Dobiveni podatci su zabilježeni. Iz čitača ELISA-e podatci su uzimani svakih 6 sati i ponovljeni dva puta. Tijekom pokusa ploče su stavljene $u$ inkubator i držane na temperaturi od $37^{\circ} \mathrm{C} \mathrm{u} 100 \%$ vlažnom okružju. Podatci su dobiveni za svaki uzorak u razdoblju od 0 , 6, 12, 18, 24, 30, 36, 42 i 48 sati. Prosječni podatci dobiveni pri svakom mjerenju izračunati su zasebno za svaku skupinu, a prosječna vrijednost OG-a utvrđena je za svako razdoblje. Korišteni su prosječni OG podatci dobiveni za svaki uzorak za svako razdoblje, a kreiran je vremenski ovisan grafikon promjene OG-a za svaku pokusnu skupinu (slika 2., 4. - 10.)

Za statističku analizu korišteni su Kruskal-Wallisov test i Mann-Whitneyjev U-test kako bi se utvrdile razlike među ispitivanim skupinama. Razina značajnosti prihvaćena je na $\mathrm{p}>0,05$. 

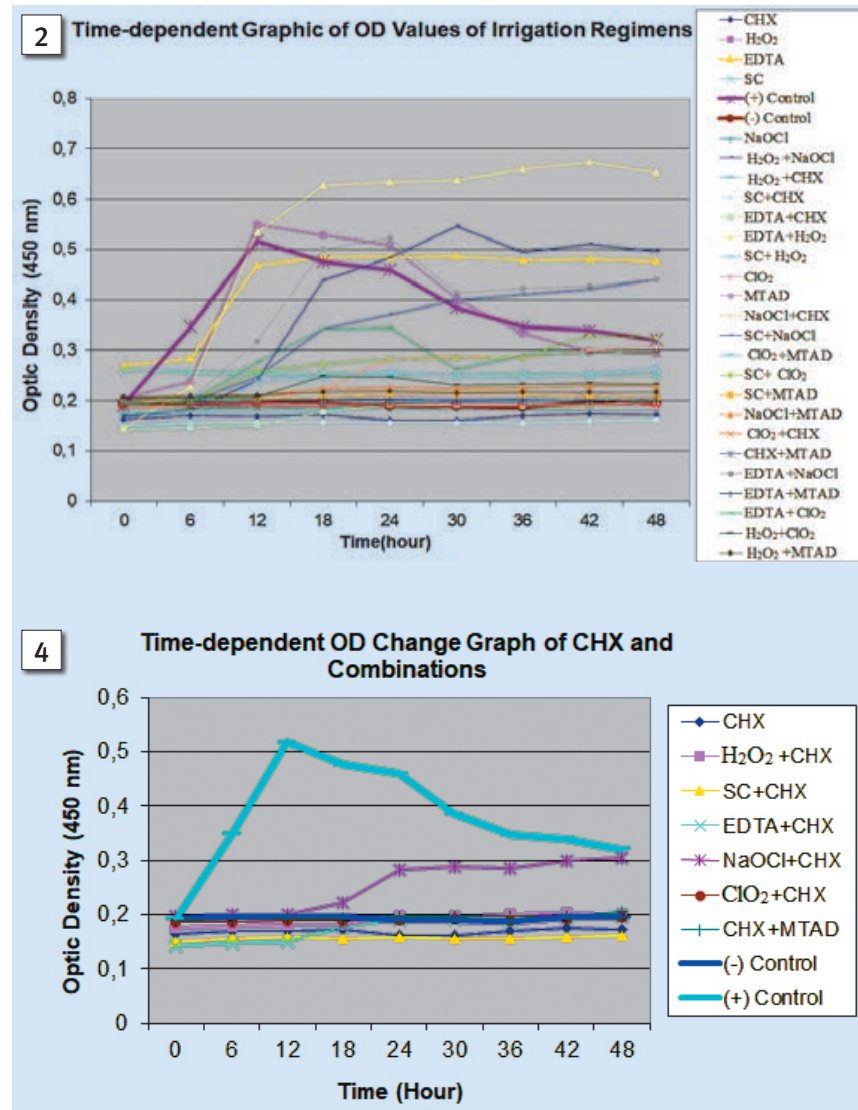

\section{Time-dependent $\mathrm{OD}$ change graph of $\mathrm{NaOCl}$ and its}

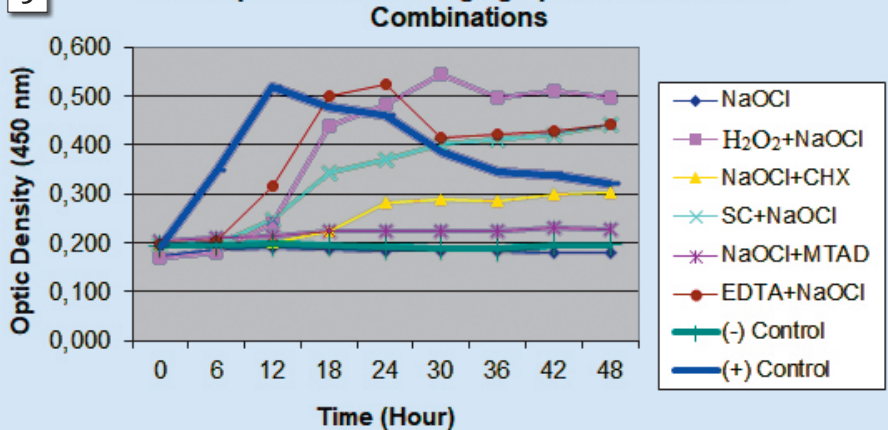

\section{3}
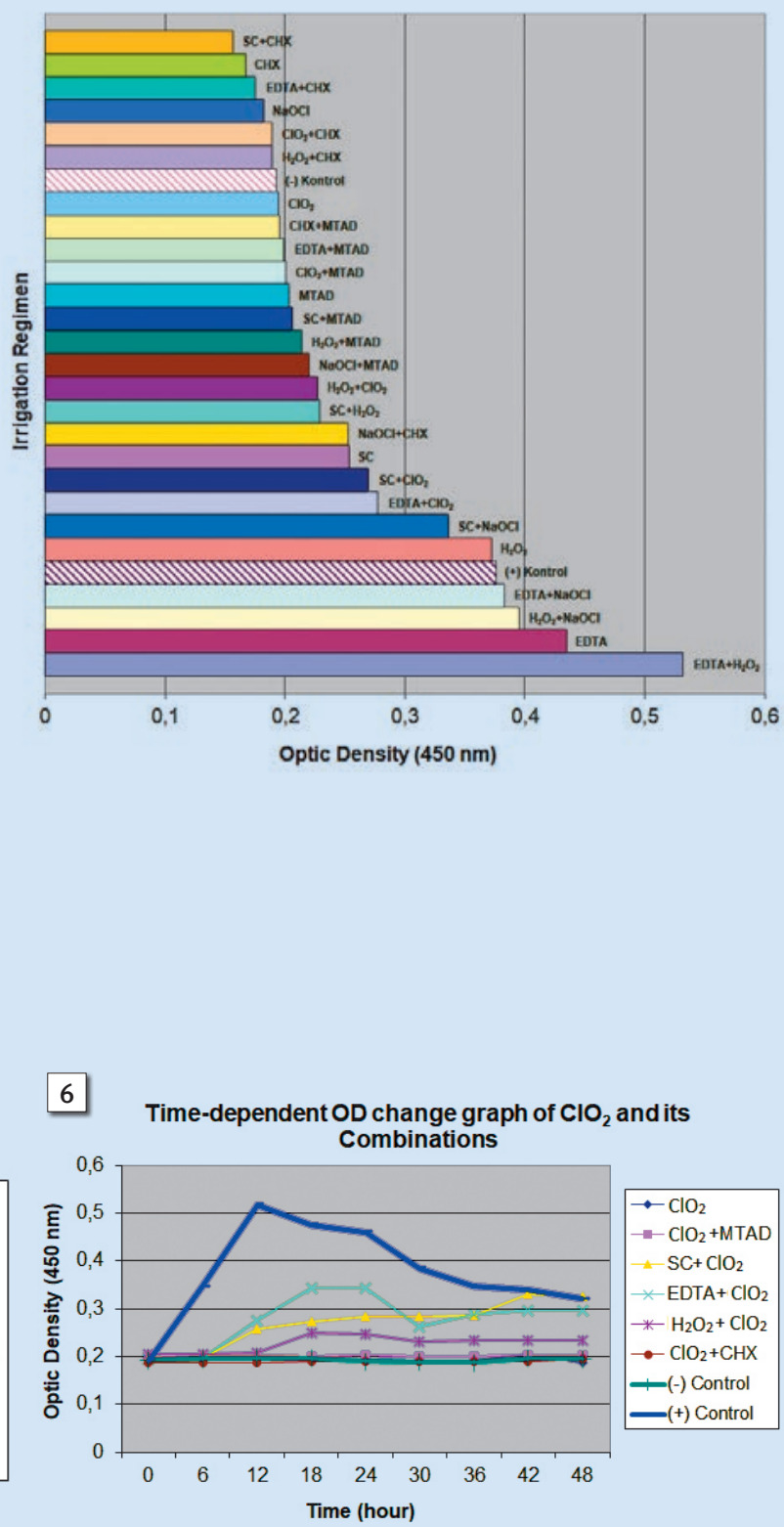

Figure 2 Bacterial growth curves resulting from time-dependent OD values

Slika 2. Krivulje rasta bakterija koje su rezultat vremenski ovisnih OG vrijednosti

Figure 3 Mean OD values of irrigation regimens used in the experiment

Slika 3. Srednje vrijednosti OG-a za irigaciju korištene u pokusu

Figure $4 \mathrm{CHX}$ and Combinations

Slika 4. CHX i kombinacije

Figure $5 \mathrm{NaOCl}$ and Combinations

Slika 5. $\mathrm{NaOCl}$ i kombinacije

Figure $6 \mathrm{ClO}_{2}$ and Combinations

Slika 6. $\mathrm{ClO}_{2}$ i kombinacije

\section{Results}

The post-incubation, time-dependent OD values (at 450 $\mathrm{nm}$ ) of the samples tested for antibacterial activity following single and combined uses of the root canal solutions are shown in Figure 2.

Overall statistical results showed that significant similarity was found between the OD values of samples taken from root canals irrigated with $\mathrm{CHX}, \mathrm{NaOCl}, \mathrm{MTAD}, \mathrm{SC}$ and

\section{Rezultati}

Postinkubacija i OG vrijednosti uzoraka ovisnih o vremenu $(\mathrm{na} 450 \mathrm{~nm})$ testiranih na antibakterijsko djelovanje nakon pojedinačnih i kombiniranih primjena otopina korijenskog kanala prikazani su na slici 2 .

Ukupni statistički rezultati pokazali su da je pronađena značajna sličnost između OG vrijednosti uzoraka uzetih iz korijenskih kanala irigiranih $\mathrm{CHX}-\mathrm{om}, \mathrm{NaOCl}-\mathrm{om}, \mathrm{MTAD}$ - 

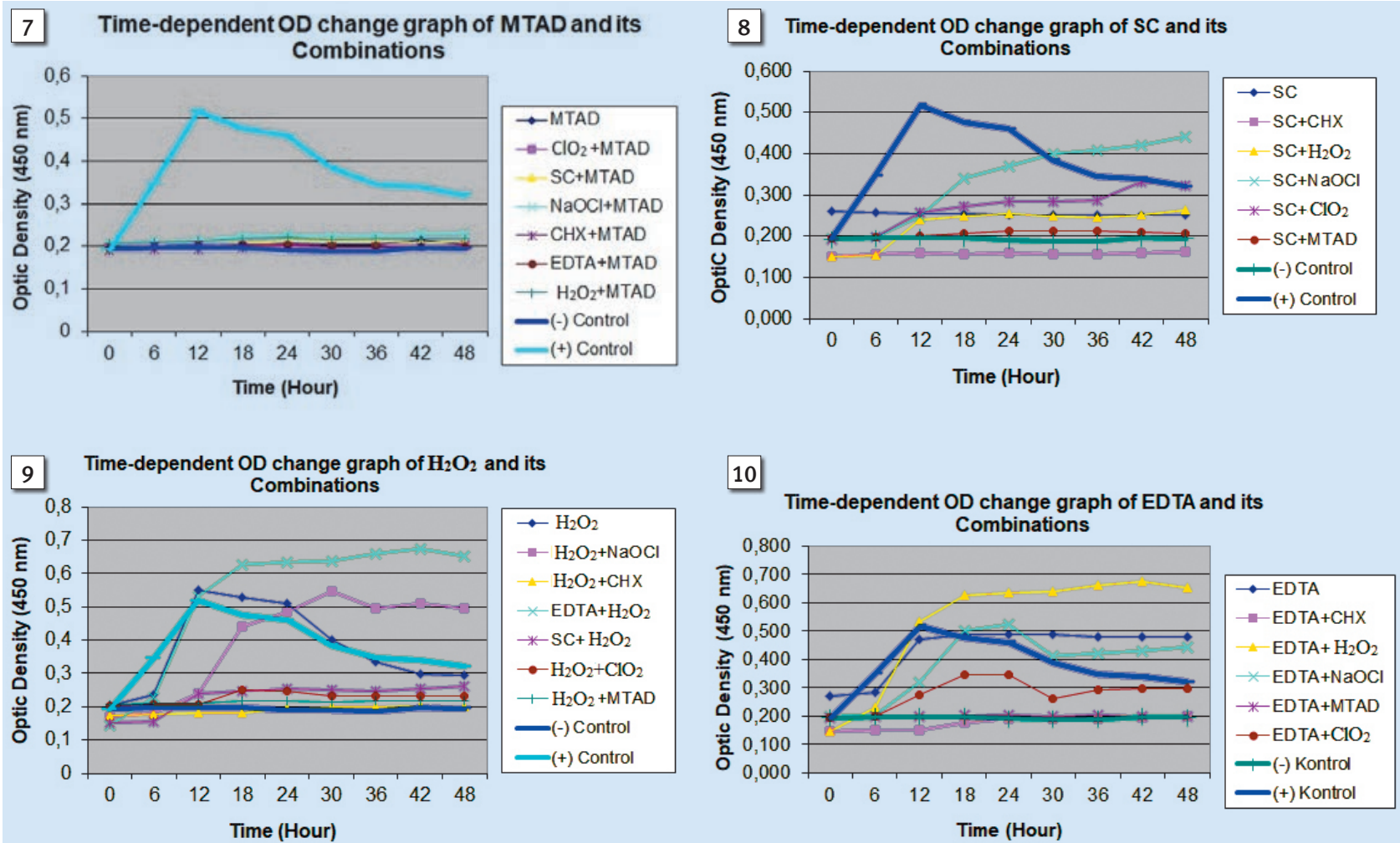

Figure 7 MTAD and Combinations

Slika 7. MTAD i kombinacije

Figure 8 SC and Combinations

Slika 8. SC i kombinacije

Figure $9 \mathrm{H}_{2} \mathrm{O}_{2}$ and Combinations

Slika 9. $\mathrm{H}_{2} \mathrm{O}_{2}$ i kombinacije

Figure 10 EDTA and Combinations

Slika 10. EDTA i kombinacije

$\mathrm{ClO}_{2}$ and the negative control group ( $\left.\mathrm{p}>0.05\right)$. On the other hand, the positive control group showed significant similarities with OD values of the samples taken from the root canals irrigated with $\mathrm{H}_{2} \mathrm{O}_{2}$ and EDTA ( $\mathrm{p}>0.05$ ).

\section{$\mathrm{CHX}$ and $\mathrm{CHX}$ combinations}

No statistically significant difference was found between the negative control group and $\mathrm{CHX}$ and its combinations at all times, including the $\mathrm{NaOCl}+\mathrm{CHX}$ group, which showed an increase in OD values (Figure 2,4) ( $>>0.05)$.

\section{$\mathrm{NaOCl}$ and $\mathrm{NaOCl}$ combinations}

No statistically significant difference was found between the $\mathrm{NaOCl}$ and $\mathrm{NaOCl}+\mathrm{MTAD}$ groups and the negative control group at all times $(\mathrm{p}>0.05)$. The values of samples irrigated with $\mathrm{H}_{2} \mathrm{O}_{2}+\mathrm{NaOCl}$ and EDTA $+\mathrm{NaOCl}$ at hours 24,36 and 48 were found to be similar with the positive control group ( $>0.05$ ) (Figure 5). The increase in the OD value of the $\mathrm{SC}+\mathrm{NaOCl}$ group after hour 6 was found to be significantly different from the negative control group after hour $36(\mathrm{p}<0.05)$ (Figure 5).

\section{$\mathrm{ClO}_{2}$ and $\mathrm{ClO}_{2}$ combinations}

$\mathrm{ClO}_{2}$ and all its combinations were found to be significantly similar with the negative control group at all times $(\mathrm{p}>0.05)$ (Figure 6). om, SC-om i $\mathrm{ClO}_{2}$ i negativne kontrolne skupine ( $\left.\mathrm{p}>0,05\right)$. $S$ druge strane, pozitivna kontrolna skupina imala je značajne sličnosti s vrijednostima OG uzoraka uzetih iz korijenskih kanala irigiranih otopinama $\mathrm{H}_{2} \mathrm{O}_{2}$ i EDTA $(\mathrm{p}>0,05)$.

\section{CHX i njegove kombinacije}

Nije pronađena statistički značajna razlika između negativne kontrolne skupine i CHX-a i njegovih kombinacija u svim razdobljima, uključujući skupinu $\mathrm{NaOCl}+\mathrm{CHX}$ koja je pokazala porast vrijednosti OG-a (slike 2., 4.) ( $\mathrm{p}>0,05)$.

\section{$\mathrm{NaOCl}$ i njegove kombinacije}

Nije nađena statistički značajna razlika između skupina $\mathrm{NaOCl}$ i $\mathrm{NaOCl}+\mathrm{MTAD}$ te negativne kontrolne skupine u svakom trenutku $(\mathrm{p}>0,05)$. Vrijednosti uzoraka irigiranih otopinama $\mathrm{H}_{2} \mathrm{O}_{2}+\mathrm{NaOCl}$ i EDTA $+\mathrm{NaOCl}$ tijekom 24, 36 i 48 sati slične su pozitivnoj kontrolnoj skupini ( $>$ > 0,05) (slika 5.). Pokazalo se da se porast OG vrijednosti u skupini $\mathrm{SC}+\mathrm{NaOCl}$ nakon jednog sata značajno razlikuje od negativne kontrolne skupine nakon 36 sati $(\mathrm{p}<0,05)$ (slika 5.).

\section{$\mathrm{ClO}_{2}$ i njegove kombinacije}

$\mathrm{ClO}_{2}$ i sve njegove kombinacije vrlo su slične negativnoj kontrolnoj skupini u svakom trenutku $(p>0,05)$ (slika 6.). 


\section{MTAD and MTAD combinations}

No difference was found between OD values of MTAD and all its combinations and the negative control group ( $>00.05)$. (Figure 7).

\section{$\mathrm{SC}$ and SC combinations}

$\mathrm{SC}, \mathrm{SC}+\mathrm{CHX}, \mathrm{SC}+\mathrm{MTAD}$ and $\mathrm{SC}+\mathrm{H}_{2} \mathrm{O}_{2}$ were found to be statistically similar with the negative control group at all times ( $>0.05)$ (Figure 8). A continuous increase was found in the $\mathrm{OD}$ values of the groups irrigated with $\mathrm{SC}+\mathrm{ClO}_{2}$ and $\mathrm{SC}+\mathrm{NaOCl}$ at all time periods (Figure 8). While this increase was not found to be statistically significant in the group irrigated with $\mathrm{SC}+\mathrm{ClO}_{2}(\mathrm{p}>0.05)$, in the group irrigated with $\mathrm{SC}+\mathrm{NaOCl}$, it was found to be significantly different for the measurements at hours 30, 36 and 48 when compared with the negative control group $(\mathrm{p}<0.05)$.

\section{$\mathrm{H}_{2} \mathrm{O}_{2}$ and $\mathrm{H}_{2} \mathrm{O}_{2}$ combinations}

There were no statistically significant differences between the $\mathrm{OD}$ values of the groups irrigated with $\mathrm{SC}+\mathrm{H}_{2} \mathrm{O}_{2}, \mathrm{H}_{2} \mathrm{O}_{2}$ $+\mathrm{ClO}_{2}, \mathrm{H}_{2} \mathrm{O}_{2}+\mathrm{CHX}$ and $\mathrm{H}_{2} \mathrm{O}_{2}+\mathrm{MTAD}$ and those of the negative control group (Figure 9). The group irrigated with $\mathrm{H}_{2} \mathrm{O}_{2}$ was found to be statistically significantly similar with the positive control group $(p>0.05)$. The increase in the first 24-hour period in the groups irrigated with $\mathrm{H}_{2} \mathrm{O}_{2}+$ EDTA and $\mathrm{H}_{2} \mathrm{O}_{2}+\mathrm{NaOCl}$ was not statistically significant when compared with the positive control group ( $p>0.05$ ) (Figure 9). However, the increase continuing at hours 24 and 48 in the groups irrigated with $\mathrm{H}_{2} \mathrm{O}_{2}+$ EDTA and $\mathrm{H}_{2} \mathrm{O}_{2}+\mathrm{NaOCl}$ was significantly different when compared with the positive control group $(\mathrm{p}<0.05)$ (Figure 9).

\section{EDTA and EDTA combinations}

The time-dependent increase in OD values of the groups irrigated with EDTA and EDTA $+\mathrm{H}_{2} \mathrm{O}_{2}$ was found to be significantly similar with the positive control group $(\mathrm{p}>0.05)$ (Figure 10). The increase observed for the first 6 hours in the EDTA $+\mathrm{H}_{2} \mathrm{O}_{2}$ group was found to be significantly similar with the negative control group ( $p>0.05)$, while that increase was found to be significantly similar with the positive control group at hours 6 and 24 ( $p>0.05$ ). In the remaining periods, the increase in the OD values was found to be significantly different from those of the positive control group $(\mathrm{p}<0.05)$. The OD values of the group irrigated with EDTA $+\mathrm{ClO}_{2}$ were found to be similar with the negative control group at all times $(\mathrm{p}>0.05)$ (Figure 10). When the time-dependent $\mathrm{OD}$ value of EDTA $+\mathrm{NaOCl}$ was compared with the negative control group, it was found to be significantly different after hour 18 ( $\mathrm{p}<0.05)$ (Figure 10). However, no statistically significant difference was observed between the groups irrigated with EDTA + CHX and EDTA + MTAD and the negative control group $(\mathrm{p}>0.05)$ (Figure 10).

\section{Discussion}

In this study, the bacterial growth in samples from infected root canals irrigated with antibacterial irrigation solutions was compared with normal bacterial growth (positive control group), and bacterial growth from when the sterilized roots

\section{MTAD i njegove kombinacije}

Nije dokazana razlika između OG vrijednosti MTAD-a i svih njegovih kombinacija i negativne kontrolne skupine ( $\mathrm{p}$ $>0,05)$ (slika 7.).

\section{$\mathrm{SC}$ i njegove kombinacije}

$\mathrm{SC}, \mathrm{SC}+\mathrm{CHX}, \mathrm{SC}+\mathrm{MTAD}$ i SC $+\mathrm{H}_{2} \mathrm{O}_{2}$ statistički su slični negativnoj kontrolnoj skupini u svakom trenutku ( $p$ > $0,05)$ (slika 8.). Utvrđeno je kontinuirano povećanje vrijednosti OG-a u skupinama irigiranim otopinama $\mathrm{SC}+\mathrm{ClO}_{2} \mathrm{i}$ $\mathrm{SC}+\mathrm{NaOCl}$ u svim razdobljima (slika 8.). Iako se nije ustanovilo da je taj porast statistički znatan u skupini koja je irigirana otopinom $\mathrm{SC}+\mathrm{ClO}_{2}(\mathrm{p}>0,05)$, u skupini irigiranoj otopinom $\mathrm{SC}+\mathrm{NaOCl}$ ustanovljeno je da se značajno razlikuje za mjerenja u satima 30, 36 i 48 u usporedbi s negativnom kontrolnom skupinom $(\mathrm{p}<0,05)$.

\section{$\mathrm{H}_{2} \mathrm{O}_{2}$ i njegove kombinacije}

Nije bilo statistički značajnih razlika između OG vrijednosti skupina irigiranih otopinama $\mathrm{SC}+\mathrm{H}_{2} \mathrm{O}_{2}, \mathrm{H}_{2} \mathrm{O}_{2}+$ $\mathrm{ClO}_{2}, \mathrm{H}_{2} \mathrm{O}_{2}+\mathrm{CHX}$ i $\mathrm{H}_{2} \mathrm{O}_{2}+$ MTAD i vrijednosti negativne kontrolne skupine (slika 9.). Uočeno je da je skupina irigirana otopinom $\mathrm{H}_{2} \mathrm{O}_{2}$ statistički značajno slična pozitivnoj kontrolnoj skupini $(\mathrm{p}>0,05)$. Povećanje u prva 24 sata u skupinama irigiranima otopinama $\mathrm{H}_{2} \mathrm{O}_{2}+$ EDTA i $\mathrm{H}_{2} \mathrm{O}_{2}$ $+\mathrm{NaOCl}$ nije bilo statistički značajno u usporedbi s pozitivnom kontrolnom skupinom ( $>$ > 0,05) (slika 9.). No porast koji se nastavio tijekom 24 i 48 sati u skupinama irigiranima otopinama $\mathrm{H}_{2} \mathrm{O}_{2}+$ EDTA i $\mathrm{H}_{2} \mathrm{O}_{2}+\mathrm{NaOCl}$ bio je značajno drukčiji u usporedbi s pozitivnom kontrolnom skupinom (p $<0,05)$ (slika 9.).

\section{EDTA i njezine kombinacije}

Otkriveno je da vremenski ovisan porast vrijednosti OG grupe irigirane otopinama EDTA i EDTA $+\mathrm{H}_{2} \mathrm{O}_{2}$ značajno sliči pozitivnoj kontrolnoj skupini ( $p>0,05)$ (slika 10.). Pokazalo se da je porast zabilježen u prvih 6 sati u skupini ED$\mathrm{TA}+\mathrm{H}_{2} \mathrm{O}_{2}$ značajno sličan negativnoj kontrolnoj skupini ( $\mathrm{p}$ $>0,05$ ), a ustanovljeno je da je taj porast vrlo sličan pozitivnoj kontrolnoj skupini nakon 6 i 24 sata $(p>0,05)$. U preostalim razdobljima uočeno je da se porast vrijednosti OG-a značajno razlikuje od vrijednosti pozitivne kontrolne skupine $(\mathrm{p}<0,05)$. Istaknuto je da su OG vrijednosti za skupinu irigiranu otopinom EDTA $+\mathrm{ClO}_{2}$ u svakom trenutku slične negativnoj kontrolnoj skupini $(\mathrm{p}>0,05)$ (slika 10.). Kad se usporedila vremenski ovisna OG vrijednost EDTA + NaOCl-a s negativnom kontrolnom skupinom, ustanovljeno je da se značajno razlikuju nakon 18 sati $(\mathrm{p}<0,05)$ (slika 10.). No nije opažena statistički značajna razlika između skupina irigiranih otopinama EDTA + CHX i EDTA + MTAD i negativne kontrolne skupine $(\mathrm{p}>0,05)$ (slika 10.).

\section{Rasprava}

U ovom istraživanju je rast bakterija u uzorcima iz zaraženih kanala korijena koji se vlaže antibakterijskim otopinama za irigaciju uspoređen $s$ normalnim rastom bakterija (pozitivna kontrolna skupina) i rastom bakterija nakon inkubaci- 
were incubated (negative control group). During the incubation period, it was clearly determined in which period the reproduction occurred, slowed down and regressed.

The antibacterial activity of irrigation solutions is known to increase with the increase in volume and application time of the irrigation $(10,11)$. In this study, the standard irrigation application time was determined to be a total of $5 \mathrm{~min}$ of irrigation with a $5 \mathrm{ml}$ solution for all canals. In combined uses, the total volume used was $2.5 \mathrm{ml}+2.5 \mathrm{ml}$ for each solution. For MTAD, the manufacturer recommended an application regimen of $5 \mathrm{ml}$ for each canal. Thus, MTAD also used the same volume and time interval as the other solutions, making all solutions in the experiment comparable. All of the root canals were also irrigated at a post-experiment stage with $5 \mathrm{ml}$ saline to achieve maximum dilution of the residual solution. In this way, the impact of the transferred solution on the medium was minimized and the residual antibacterial effect was reduced.

In this study, the order of the solution application recommended by researchers was used $(12,13)$. It is acknowledged that a residual antimicrobial effect might still be present unless the activity of the solution is neutralized by means of an inactivator (14). However, to be able to standardize the experiments undertaken in this study, neutralization of the test solutions was not carried out. One of the other reasons for this is that some of the test solutions, such as MTAD and SC, are proprietary products and there are no chemical inactivators known to exist for them. Therefore, to achieve uniformity in the experiment methodology and to make it an easier procedure to compare the relatively high number of solutions, none of the test specimens were inactivated.

It has been reported by many researchers that CHX shows antibacterial activity against $E$. faecalis $(15,16,17)$. In accordance with other studies, no significant increase in the $\mathrm{OD}$ values of $\mathrm{CHX}$ and its combinations (except $\mathrm{NaOCl}+$ $\mathrm{CHX}$ ) were observed in this recent study. However, $\mathrm{NaOCl}$ + CHX showed less antibacterial activity with increased OD values. This may be due to the orange-colored residue made of parachlorophenol (PCU) or chloropfenilguanidil-1,6-diguanidil-hexaze (PCGH), which can be obtained when CHX and $\mathrm{NaOCl}$ are combined $(18,19)$. These residues may have had negative effects on the interaction between the root filling and the canal wall dentin by blocking dentin tubules (18, $20)$. In order to prevent these solution's interaction, it is recommended to irrigate the root canals with saline, sterile distilled water or alcohol before irrigation with $\mathrm{CHX}$, and $\mathrm{NaO}$ $\mathrm{Cl}$ left in the canal can be aspirated with a needle, dried with paper cones or ultrasonic activation with EDTA $(20,21,22)$. However, in the present study, the recommended processes to prevent the interaction of these two solutions mentioned above were not used because of their variations in the experimental procedure. Another important issue noted with the $\mathrm{NaOCl}+\mathrm{CHX}$ group is that the antibacterial activity did not decrease in the first 12 hours but did decrease after hour 12 (Figure 4). This may be because of the residue that accumulated on the root canal while taking the sample, and/or the possibility of PCU and PCGH being toxic to E. faecalis and the decrease observed in these effects at the end of hour 12 . je steriliziranih korijena (negativna kontrolna skupina). Tijekom razdoblja inkubacije bilo je jasno određeno u kojemu se razdoblju reprodukcija događala, usporila i nazadovala.

Poznato je da se antibakterijska aktivnost otopina za irigaciju povećava s povećanjem volumena i vremenom primjene irigacije $(10,11)$. U ovoj je studiji utvrdeno da standard irigacije uključuje vrijeme od ukupno 5 minuta $s 5 \mathrm{~mL}$ otopine za sve kanale. U kombiniranim otopinama ukupni upotrijebljeni volumen bio je $2,5 \mathrm{~mL}+2,5 \mathrm{~mL}$ za svaku otopinu. $\mathrm{Za}$ MTAD je proizvođač preporučio primjenu od $5 \mathrm{~mL}$ za svaki kanal. Zato je za MTAD također korišten jednaki interval volumena i vremena kao i za ostale otopine, čineći tako sve otopine u pokusu usporedivima. Svi se korijenski kanali također irigiraju u fazi nakon pokusa s $5 \mathrm{~mL}$ fiziološke otopine kako bi se postiglo maksimalno razrjedivanje zaostale otopine. $\mathrm{Na}$ taj je način utjecaj prenesene otopine na medij sveden na minimum, a zaostali antibakterijski učinak je smanjen.

U ovom istraživanju korišten je redoslijed primjene otopina koji su preporučili istraživači $(12,13)$. Potvrđeno je da je zaostali antimikrobni učinak još prisutan ako se aktivnost otopine ne neutralizira inaktivatorima (14). No kako bi se mogli standardizirati pokusi provedeni u ovom istraživanju, nije obavljena neutralizacija ispitanih otopina. Jedan od razloga jest $\mathrm{i}$ to što su neke ispitane otopine, poput MTAD-a i SC-a, zaštićeni proizvodi za koje nije poznato postoje li kemijski inaktivatori. Zato, kako bi se postigla jedinstvenost u metodologiji pokusa i olakšao proces za usporedbu razmjerno velikog broja otopina, nijedan testni uzorak nije bio inaktiviran.

Mnogi su istraživači istaknuli da CHX pokazuje antibakterijsko djelovanje na $E$. faecalis $(15,16,17)$. U skladu s drugim studijama, u ovom nedavnom istraživanju nije uočeno značajno povećanje OG vrijednosti za CHX i njegove kombinacije (osim $\mathrm{NaOCl}+\mathrm{CHX}$ ). No $\mathrm{NaOCl}+\mathrm{CHX}$ pokazao je manje antibakterijske aktivnosti s povećanim vrijednostima OG-a. To se može dogoditi zbog narančasto obojenih ostataka izgrađenih od paraklorofenola (PCU) ili kloropfenilguanidil-1,6-diguanidil-heksaza (PCGH) koji se mogu dobiti kada se kombiniraju CHX i $\mathrm{NaOCl}(18,19)$. Ti ostatci mogu negativno utjecati na interakciju između korijenskog punjenja i dentinskih stijenki kanala te blokirati dentinske tubuluse (18, 20). Kako bi se spriječila interakcija tih otopina preporučuje se irigacija korijenskih kanala fiziološkom otopinom, sterilnom destiliranom vodom ili alkoholom prije irigacije CHXom, a $\mathrm{NaOCl}$ koji je ostavljen u kanalu može se aspirirati iglom, osušiti papirnatim štapićima ili ultrazvučnom aktivacijom EDTA-e $(20,21,22)$. No u ovoj studiji preporučeni postupci za sprječavanje interakcije spomenutih otopina nisu korišteni zbog njihovih varijacija u pokusnom postupku. Drugo što je važno, a zabilježeno je kod skupine $\mathrm{NaOCl}+$ $\mathrm{CHX}$ jest da se antibakterijska aktivnost nije smanjila u prvih 12 sati, nego nakon 12 sati (slika 4.). Razlog mogu biti ostatci koji su nakupljeni u korijenskom kanalu tijekom uzimanja uzorka i/ili mogućnosti da su PCU i PCGH toksični za $E$. faecalis te smanjenje opaženoga nakon 12 sati.

Kako nije utvrđeno povećanje OG vrijednosti u skupini EDTA + CHX tijekom vremena ( $p>0,05)$, ta kombinacija može učinkovito antibakterijski djelovati na $E$. faecalis. Liu i 
Since no increase was found in the EDTA + CHX group's OD values over time $(p>0.05)$, this combination has the potential to show effective antibacterial activity against $E$. faecalis. Liu et al. (23) reported that the combined use of CHX and EDTA had antibacterial activity and it was also. better than MTAD and EDTA $+\mathrm{NaOCl}$. The present study also supports these results. Gonzalez-Lopez et al. (24) observed a pink-colored residue when CHX and EDTA were mixed. In their study, Rasimick et al. (25) showed a white-colored salt when these two materials were mixed. Later, Prado et al. (21) examined the interaction of CHX and EDTA and observed a milky residue and concluded that this was a result of an acidbase reaction of the combination. The results of the present study confirmed that the white and/or salt residue formed by these two materials does not negatively affect the antibacterial activity of CHX in infected root canals.

No studies have been conducted so far on whether $\mathrm{ClO}_{2}+$ $\mathrm{CHX}$ shows antibacterial activity against $E$. faecalis. According to the results of the present study, $\mathrm{ClO}_{2}+\mathrm{CHX}$ is effective in the elimination of $E$. faecalis. These two agents do not form any reactions nor do they negatively influence each other $(26,27)$ and they maintain their antibacterial activity at all times when used in combinations (Figure 4,6).

Although it has been reported in a great number of studies that MTAD has antibacterial activity against $E$. faecalis $(23,28)$, no studies have been found comparing the antibacterial characteristics of CHX + MTAD to MTAD. The results of this study showed that the CHX + MTAD and MTAD groups have similar antibacterial activities against $E$. faecalis ( $>0.05$ ) (Figure 7). The CHX + MTAD combination did not cause any negative change in the antibacterial characteristics of either solution. This important characteristic can be evaluated with further studies not only on $E$. faecalis but also on the elimination of other bacteria that are also responsible for endodontic infections.

In this study, an increase was found in the OD value of the $\mathrm{H}_{2} \mathrm{O}_{2}+\mathrm{NaOCl}$ group after 12 hours, and this increase was found to be different from the negative control group's $(\mathrm{p}<0.05)$ (Figure 5,9). The combined use of these two solutions has been recommended to ease organic and inorganic debris from the root canal, and it has disinfecting and whitening properties through its foaming effect (29). The antibacterial activity of an irrigant increases as its volume increases (30). Since, $\mathrm{NaOCl}^{\prime}$ v volume in combined use is less than when it is used alone, a decrease in antibacterial activity is expected. The antibacterial activity of $\mathrm{H}_{2} \mathrm{O}_{2}$ was also found to be insufficient in the present study. Therefore, it was speculated that the combined use of these two solutions did not positively contribute to the solutions' antibacterial characteristics. Another reason for the decreased antibacterial activity may be due to decreased hydroxyl radicals, which actually creates antibacterial activity with the reaction of the two solutions (31).

In the EDTA $+\mathrm{NaOCl}$ and $\mathrm{SC}+\mathrm{NaOCl}$ groups, a timedependent increase was found in measurements after hour 6 (Figure 5). When compared to the negative control group, the antibacterial activity in the EDTA $+\mathrm{NaOCl}$ group was found to be less than the activity in the $\mathrm{SC}+\mathrm{NaOCl}$ group. The reason for the decrease in antibacterial activity may be suradnici (23) pokazali su da kombinirana primjena CHXa i EDTA-e ima antibakterijsko djelovanje, te da je također uspješnija od kombinacije MTAD-a i EDTA + $\mathrm{NaOCl}$. Ova studija takoder podupire te rezultate. Gonzalez-Lopez i suradnici (24) uočili su ostatak ružičaste boje kada su se pomiješali CHX i EDTA-u. U svojoj studiji su Rasimick i suradnici (25) istaknuli da su dobili sol bijele boje kada su miješali ta dva materijala. Poslije su Prado i suradnici (21) ispitali interakciju CHX-a i EDTA-e i uočili mliječni ostatak te zaključili da je to rezultat kiselo-bazne reakcije kombinacije. Rezultati ove studije potvrdili su da bijeli ostatak i/ ili sol stvorena $s$ tim dvama materijalima ne utječe negativno na antibakterijsko djelovanje CHX-a u zaraženim korijenskim kanalima.

Do sada nisu provedena ispitivanja djeluje $\mathrm{li}_{\mathrm{ClO}_{2}}+$ CHX antibakterijski na E. faecalis. Prema rezultatima ove studije, $\mathrm{ClO}_{2}+\mathrm{CHX}$ učinkovito uklanjanju tu bakteriju. Ta dva sredstva ne stvaraju nikakvu reakciju, niti negativno utječu jedno na drugo $(26,27)$ i zadržavaju svoje antibakterijsko djelovanje u svakom trenutku kada se koriste u kombinacijama (slika 4., 6.).

Iako je u mnogim studijama objavljeno da MTAD antibakterijski djeluje na $E$. faecalis $(23,28)$, nisu pronađena istraživanja u kojima su autori uspoređivali antibakterijska svojstva CHX + MTAD-a i MTAD-a. Rezultati ove studije pokazali su da skupine CHX + MTAD i MTAD imaju slične antibakterijske aktivnosti kad je riječ o E. faecalis $(\mathrm{p}>0,05)$ (slika 7.). Kombinacija CHX + MTAD nije uzrokovala nikakve negativne promjene u antibakterijskim karakteristikama ni u jednoj otopini. Ovo važno svojstvo može se procijeniti u daljnjim istraživanjima ne samo na $E$. faecalis, nego i u uklanjanju drugih bakterija koje su također odgovorne za endodontske infekcije.

$\mathrm{U}$ ovom istraživanju prikazano je povećanje vrijednosti u skupini $\mathrm{OG} \mathrm{H}_{2} \mathrm{O}_{2}+\mathrm{NaOCl}$ nakon 12 sati, a utvrđeno je da se taj porast razlikuje od onoga u negativnoj kontrolnoj skupini $(\mathrm{p}<0,05)($ slike 5., 9.). Preporučuje se kombinirana upotreba tih dviju otopina za ublažavanje organskih i anorganskih nečistoća iz korijenskog kanala, a kako se pjene, imaju svojstva dezinfekcije i izbjeljivanja (29). Antibakterijsko djelovanje irigansa povećava se s povećanjem volumena (30). Budući da je volumen natrijeva hipoklorita u kombiniranoj uporabi manji negoli kada se koristi sam, očekuje se smanjenje antibakterijske aktivnosti. $U$ ovoj studiji također je utvrđeno nedovoljno antibakterijsko djelovanje $\mathrm{H}_{2} \mathrm{O}_{2}$. Zato se nagadalo da kombinirana primjena tih dviju otopina ne pridonosi pozitivno antibakterijskim svojstvima otopina. Drugi razlog za smanjene antibakterijske aktivnosti može biti smanjenje hidroksilnih radikala, što zapravo stvara antibakterijsko djelovanje reakcijom dviju otopina (31).

U skupinama EDTA $+\mathrm{NaOCl}$ i $\mathrm{SC}+\mathrm{NaOCl}$ utvrđeno je vremenski ovisno povećanje u mjerenjima nakon 6 sati (slika 5.). U usporedbi s negativnom kontrolnom skupinom, istaknuto je da je antibakterijska aktivnost u skupini EDTA $+\mathrm{NaOCl}$ manja od one u skupini $\mathrm{SC}+\mathrm{NaOCl}$. Razlog za to može biti negativni učinak EDTA-e na tkivno otapanje natrijeva hipoklorita i smanjenje količine aktivnoga klora u kombinaciji (32). 
related to EDTA's negative effect on the tissue-dissolving capacity of $\mathrm{NaOCl}$ and decrease in the amount of active chlorine in the combination (32).

It has previously been reported that $\mathrm{NaOCl}+\mathrm{MTAD}$ is successful in E. faecalis elimination (33). Tay et al. (34) reported a brown liquid developed when $\mathrm{NaOCl}$ and MTAD were combined and that this combination decreased the dentine substantivity of MTAD (35). For these reasons, it has been reported that the canals need to be irrigated in intervals with saline. In the present study, no decrease was found in the combination's antibacterial activity. Thus, the results of the current study support Shabahang and Torabinejad's study (13), which states that the antibacterial effect of the combination of $1.3 \% \mathrm{NaOCl}$ and $\mathrm{MTAD}$ is an effective solution in eradicating $E$. faecalis.

$\mathrm{ClO}_{2}$ is a strong oxidizing agent, and it effectively kills pathogenic microorganisms (36). $\mathrm{ClO}_{2}$ actually has smear layer removing characteristics and the capacity to dissolve organic tissue (37-42). In this study, it was found that when used alone and in combination with other solutions, $\mathrm{ClO}$ showed similar antibacterial characteristics with $\mathrm{NaOCl}$ and its combinations against $E$. faecalis. However, $\mathrm{ClO}_{2}$ and the $\mathrm{SC}+\mathrm{ClO}_{2}, \mathrm{EDTA}+\mathrm{ClO}_{2}, \mathrm{H}_{2} \mathrm{O}_{2}+\mathrm{ClO}_{2}$ and $\mathrm{ClO}_{2}+\mathrm{CHX}$ combinations showed relatively higher antibacterial characteristics compared to the $\mathrm{NaOCl}$ combinations (Figure 6). These results are parallel to Eddy et al.'s findings (37), which stated $10 \%$ and $13.8 \%$ Chlorine dioxide and $5.25 \% \mathrm{NaO}$ $\mathrm{Cl}$ were both effective in eliminating $E$. faecalis from the dentinal disks within $30 \mathrm{~min}$.

According to the results of the present study, a fair amount of increase was found in the $\mathrm{OD}$ values of the $\mathrm{EDTA}+\mathrm{ClO}_{2}$ and $\mathrm{SC}+\mathrm{ClO}_{2}$ groups; however, this increase was found to be statistically similar to the negative control group ( $p>0.05)$ (Figure 6). This increase in the OD levels of the EDTA + $\mathrm{ClO}_{2}$ group may be due to the decrease in antibacterial activity as a result of the $\mathrm{ClO}_{2}$-oxidizing effect against EDTA (26). In addition, this increase in the OD values of the samples treated with $\mathrm{SC}+\mathrm{ClO}_{2}$ was found to be lower than that of EDTA $+\mathrm{ClO}_{2}$ (Figure 6). This may be due to the antibacterial characteristic of the surface-active agent (cetrimide) in SC (43). Since there are no studies researching the antibacterial activity of $\mathrm{SC}+\mathrm{ClO}_{2}$ combinations, further studies are needed to explain the reasons for this increase.

There was a continuous increase in the OD values of the $\mathrm{SC}+\mathrm{ClO}_{2}$ and $\mathrm{SC}+\mathrm{NaOCl}$ groups in the $\mathrm{OD}$ measurements after hour 6 (Figure 8). While the $\mathrm{SC}+\mathrm{ClO}_{2}$ group's increase was found to be significantly similar to the negative control group's ( $p>0.05$ ) at all hours (Figure 8$)$, the measurements at hours 30,36 and 48 in the $\mathrm{SC}+\mathrm{NaOCl}$ group were found to be significantly higher than those of the negative control group's $(\mathrm{p}<0.05)$ (Figure 8). Thus, $\mathrm{SC}+\mathrm{ClO}_{2}$ showed better antibacterial activity than $\mathrm{SC}+\mathrm{NaOCl}$. This may be lower inhibitory effect of $\mathrm{SC}$ on $\mathrm{ClO}_{2}$ than the inhibitory effect of $\mathrm{NaOCl}$.

A time-dependent increase was found in the EDTA + $\mathrm{H}_{2} \mathrm{O}_{2}$ group. Although the increase in the OD values of ED$\mathrm{TA}+\mathrm{H}_{2} \mathrm{O}_{2}$ within the first 18 hours was significantly similar to the positive control group ( $p>0.05$ ), it was significant-
Prije je objavljeno da je $\mathrm{NaOCl}+\mathrm{MTAD}$ uspješan u uklanjanju $E$. faecalis (33). Tay i suradnici (34) ističu da je smeđa tekućina nastala kada su kombinirani $\mathrm{NaOCl}$ i MTAD te da je ta kombinacija smanjila dentinsku vezu MTAD-a (35). Iz tih je razloga objavljeno da se kanali trebaju u intervalima irigirati fiziološkom otopinom. $U$ ovoj studiji nije uočeno smanjenje antibakterijskog djelovanja te kombinacije. Dakle, rezultati ove studije podupiru Shabahangovu i Torabinejadovu studiju (13) u kojoj se ističe da je antibakterijski učinak kombinacije 1,3-postotnoga natrijeva hipoklorida i MTAD-a učinkovito rješenje u iskorjenjivanju $E$. faecalis.

$\mathrm{ClO}_{2}$ snažno je oksidacijsko sredstvo i učinkovito ubija patogene mikroorganizme (36). Zapravo ima svojstva uklanjanja zaostatnog sloja i otapanja organskoga tkiva $(37-42)$. U ovoj studiji ustanovljeno je da, kada se koristi sam i u kombinaciji s drugim otopinama, $\mathrm{ClO}_{2}$ ima slična antibakterijska svojstva kao i $\mathrm{NaOCl}$ i njegove kombinacije kad je riječ o $E$. faecalis. No kombinacije $\mathrm{ClO}_{2}$ i $\mathrm{SC}+\mathrm{ClO}_{2}, \mathrm{EDTA}+\mathrm{ClO}_{2}$, $\mathrm{H}_{2} \mathrm{O}_{2}+\mathrm{ClO}_{2} \mathrm{i} \mathrm{ClO}_{2}+\mathrm{CHX}$ pokazale su razmjerno bolja antibakterijska svojstva u usporedbi s kombinacijama u kojima je $\mathrm{NaOCl}$ (slika 6.). Ti su rezultati jednaki kao i u izvješćima Eddyja i ostalih (37) koji su izjavili da su 10-postotni i 13,8-postotni klorov dioksid te 5,25-postotni $\mathrm{NaOCl}$ djelotvorni u uklanjanju $E$. faecalis iz dentinskih diskova u roku od 30 minuta.

Prema rezultatima dobivenima u ovoj studiji, ustanovljen je priličan porast vrijednosti OG-a u skupinama EDTA $+\mathrm{ClO}_{2}$ i SC $+\mathrm{ClO}_{2}$ no ustanovljeno je da je taj porast statistički sličan negativnoj kontrolnoj skupini $(\mathrm{p}>0,05)$ (slika 6.). To povećanje razine OG-a u skupini EDTA $+\mathrm{ClO}_{2}$ može biti posljedica smanjenja antibakterijske aktivnosti kao rezultat učinka oksidacije $\mathrm{ClO}_{2}$ na EDTA-u (26). Uz to, utvrđeno je da je to povećanje OG vrijednosti uzoraka tretiranih s otopinom $\mathrm{SC}+\mathrm{ClO}_{2}$ niže od onih tretiranih otopinom EDTA + $\mathrm{ClO}_{2}$ (slika 6.). To može biti posljedica antibakterijskih svojstava površinski aktivnoga agensa (cetrimida) u SC-u (43). Budući da ne postoje studije u kojima je istraženo antibakterijsko djelovanje kombinacija $\mathrm{SC}+\mathrm{ClO}_{2}$, potrebne su dodatna istraživanja za objašnjenje toga porasta.

Zabilježeno je kontinuirano povećanje OG vrijednosti u skupinama $\mathrm{SC}+\mathrm{ClO}_{2}$ i SC + $\mathrm{NaOCl}$ u OG mjerenjima nakon 6 sati (slika 8.). Dok je uočeno da je porast u skupini SC $+\mathrm{ClO}_{2}$ vrlo sličan negativnoj kontrolnoj skupini ( $\left.\mathrm{p}>0,05\right)$ u svim satima (slika 8.), rezultati mjerenja poslije 30, 36 i 48 sati u skupini $\mathrm{SC}+\mathrm{NaOCl}$ bili su značajno veći od onih u negativnoj kontrolnoj skupini $(\mathrm{p}<0,05)$ (slika 8.). Zato je kombiniranje $\mathrm{SC}+\mathrm{ClO}_{2}$ pokazalo bolje antibakterijsko djelovanje od onoga u skupini $\mathrm{SC}+\mathrm{NaOCl}$. To može biti posljedica nižega inhibicijskog učinka SC-a na $\mathrm{ClO}_{2}$ od inhibicijskog učinka natrijeva hipoklorita.

Nadalje, utvrđeno je povećanje ovisno o vremenu u skupini EDTA $+\mathrm{H}_{2} \mathrm{O}_{2}$. Iako je porast OG vrijednosti EDTA + $\mathrm{H}_{2} \mathrm{O}_{2}$ u prvih 18 sati bio sličan pozitivnoj kontrolnoj skupi$n i^{2}(\mathrm{p}>0,05)$, značajno se razlikovao od pozitivne kontrolne skupine nakon 30 sati $(\mathrm{p}<0,05)$ (slika 9.). Razlog za porast u toj skupini može biti medij stvoren kombinacijom tih otopina jer je bio pogodan za rast $E$. faecalis. No potrebne su dodatne studije za potvrdu tih rezultata. 
ly different from the positive control group after hour 30 $(\mathrm{p}<0.05)$ (Figure 9). The reason for the increase in this group may be because the medium created with the combination of these solutions was a suitable medium for $E$. faecalis to grow. However, further studies are needed to confirm these results.

\section{Conclusions}

Within the limitations of this study, the following conclusions can be drawn:

EDTA is not a suitable solution for providing antibacterial activity in the irrigation process of root canals. Although it did not have any negative effects in combinations with $\mathrm{CHX}$ and MTAD, combined uses of EDTA and $\mathrm{H}_{2} \mathrm{O}_{2}$ solutions may be harmful for disinfecting the root canals since they can potentially provide a medium for bacteria reproduction; Chelation agents, such as EDTA and SC, can be used for the removal of the smear layer from the root canal walls. However, their application together with $\mathrm{NaOCl}$ reduces the antibacterial effect of these agents. For these reasons, additional irrigation with another irrigation solution and/or solution combination may be suggested; $\mathrm{ClO}_{2}$ is chemically similar to $\mathrm{NaOCl}$ and when used in combination with $\mathrm{H}_{2} \mathrm{O}_{2}, \mathrm{CHX}$, EDTA or SC, its antibacterial activities are less affected than with combinations of $\mathrm{NaOCl}$. Therefore, $\mathrm{ClO}_{2}$, with its positive properties, may be considered as an alternative to $\mathrm{Na}$ $\mathrm{OCl}$ and suitable for routine clinical use; Overall it can be concluded that the $\mathrm{SC}+\mathrm{CHX}$ combinations can be recommended as the most effective irrigation regimen against $E$. faecalis in persistent endodontic infections.

\section{Conflict of Interest}

The authors report no conflict of interest

\section{Acknowledgements}

The authors would like to thank Professor Osman Erganis from Selcuk University, Faculty of Veterinary Medicine, Department of Microbiology from for his professional support and help.

\section{Funding}

The work was supported by Selcuk University, Scientific Research Projects Coordination Unit with number 8102006 from Konya/Turkey.

\section{Contribution to the paper}

H.B.O. Carried out the study experiments, collected the data, wrote and edited the manuscript; F.K.C. Contributed to experimental design of the study, helped with analysis of the data, interpreted and discussed the results; Z.S. Contributed to experimental design of microbiological part of the study, commented on the manuscript at the microbiological stages; F.O. Contributed to research idea, commented on the manuscript at all stages, critically proof read the manuscript and gave final approval for publication.

\section{Zaključci}

Uz ograničenja u ovoj studiji mogu se izvući sljedeći zaključci:

EDTA nije prikladna otopina za postizanje antibakterijske aktivnosti pri irigaciji korijenskih kanala. Iako nije imala negativnih učinaka u kombinaciji s CHX-om i MTAD-om, kombinirana uporaba otopina EDTA i $\mathrm{H}_{2} \mathrm{O}_{2}$ može štetiti u dezinfekciji korijenskih kanala zato što mogu stvoriti medij za razmnožavanje bakterija; Sredstva za kelaciju, poput EDTA-e i SC-a, mogu se upotrijebiti za uklanjanje zaostatnog sloja sa zidova korijenskog kanala. No njihova primjena zajedno $s$ natrijevim hipikloritom smanjuje njihov antibakterijski učinak. Zato se može predložiti dodatna irigacija drugom otopinom i/ili kombinacija otopina; $\mathrm{ClO}_{2}$ je kemijski sličan natrijevu hipokloritu i kada se koristi u kombinaciji $\mathrm{s}_{2} \mathrm{O}_{2}$, CHX-om, EDTA-om ili SC-om, a njihovo antibakterijsko djelovanje manje je negoli kod kombinacija s natrijevim hipokloritom Zato se $\mathrm{ClO}_{2}$, sa svojim pozitivnim svojstvima, može smatrati alternativom natrijevu hipkloritu i prikladnim za rutinsku kliničku upotrebu; Sveukupno se može zaključiti da se kombinacija SC + CHX može preporučiti kao najučinkovitiji protokol za irigaciju u slučaju $E$. faecalis kod perzistentnih endodontskih infekcija.

\section{Sukob interesa}

Autori ističu da nisu bili u sukobu interesa.

\section{Zahvale}

Autori zahvaljuju profesoru Osmanu Erganisu iz Odjela za mikrobiologiju Veterinarskog fakulteta Sveučilišta Selcuk, na profesionalnoj potpori i pomoći.

\section{Financiranje}

Rad je poduprlo Sveučilište Selcuk, Jedinica za koordinaciju znanstveno-istraživačkih projekata pod brojem 8102006 iz Konja, Turska.

\section{Doprinosi autora}

H. B. O. - obavljala je eksperimente, prikupljala podatke te napisala i uredila rukopis; F. K. C. - pridonijela je eksperimentalnom oblikovanju studije, pomagala je pri analizi podataka, interpretirala i raspravljala o rezultatima; Z S. pridonio je eksperimentalnom oblikovanju mikrobiološkog dijela studije, komentirao rukopis u mikrobiološkoj fazi; F. O. - surađujući u istraživačkoj ideji komentirao je rukopis u svim fazama, kritički je pročitao rukopis i dao konačno odobrenje za objavljivanje. 


\section{Sažetak}

Ciljevi: U ovoj studiji istraživalo se antibakterijsko djelovanje pojedinačne i kombinirane primjene otopina za irigaciju u slučaju kontaminacije bakterijom Enterococcus faecalis. i to 5,25-postotng natrijeva hipoklorita $(\mathrm{NaOCl}), 2$-postotnog klorheksidina (CHX), 17-postotne etilendiamintetraoctene kiseline (EDTA), 3-postotnog vodikova peroksida $\left(\mathrm{H}_{2} \mathrm{O}_{2}\right.$ ), MTAD-a, SmearCleara ( SC) i 13,8-postotnog klorova dioksida $\left(\mathrm{ClO}_{2}\right)$ Materijal i metode: Nasumično je grupirano 280 jednokorijenskih ljudskih pretkutnjaka (premolara) u 26 testnih skupna i u 2 kontrolne (negativna i pozitivna) te su 24 sata inkubirane bakterijom $E$. faecalis, osim negativne kontrolne skupine. Testirani rezultati su sljedeći: $\mathrm{NaOCl}$; $\mathrm{CHX} ; \mathrm{ClO}_{2}$; MTAD; SC; EDTA; $\mathrm{H}_{2} \mathrm{O}_{2} ; \mathrm{NaOCl}+\mathrm{CHX} ; \mathrm{NaOCl}+\mathrm{MTAD} ; \mathrm{SC}+\mathrm{NaOCl}$ EDTA + $\mathrm{NaOCl}$; $\mathrm{H}_{2} \mathrm{O}_{2}+\mathrm{NaOCl} ; \mathrm{ClO}_{2}+\mathrm{CHX} ; \mathrm{CHX}+\mathrm{MTAD} ; \mathrm{SC}+\mathrm{CHX} ; \mathrm{EDTA}+\mathrm{CHX} ; \mathrm{CHX}+\mathrm{H}_{2} \mathrm{O}_{2} ; \mathrm{ClO}_{2}+\mathrm{MTAD} ; \mathrm{SC}+\mathrm{ClO}_{2}$; EDTA + $\mathrm{ClO}_{2} ; \mathrm{ClO}_{2+} \mathrm{H}_{2} \mathrm{O}_{2} ; \mathrm{SC}+$ MTAD; EDTA+MTAD; MTAD $+\mathrm{H}_{2} \mathrm{O}_{2} ; \mathrm{SC}+\mathrm{H}_{2} \mathrm{O}_{2}$ i EDTA $+\mathrm{H}_{2} \mathrm{O}_{2}$ Zabilježene vrijednosti optičke gustoće su $0,6,12,18,24,30,36,42$ i $48 \mathrm{~h}$, a za svaku otopinu stvorena je krivulja rasta bakterija. Rezultati: $\mathrm{CHX}, \mathrm{MTAD}$ i $\mathrm{ClO}_{2}$ pokazali su visok potencijal smanjenja $E$. faecalis samostalno i u svim kombinacijama. U skupinama EDTA, $\mathrm{H}_{2} \mathrm{O}_{2}, \mathrm{H}_{2} \mathrm{O}+\mathrm{EDTA}, \mathrm{H}_{2} \mathrm{O}_{2}+\mathrm{NaOCl}$ i SC $+\mathrm{NaOCl}$ postignuto je manje antibakterijsko djelovanje od onoga u ostalima. U skupini $\mathrm{SC}+\mathrm{CHX}$ zabilježen je najbolji antibakterijski učinak na E. faecalis. Zaključak: Kombinacija SC + CHX može se preporučiti kao najučinkovitiji protokol za irigaciju u slučaju dugotrajnih endodontskih infekcija s $E$. faecalis.
Zaprimljen: 30. svibnja 2020.

Prihvaćen: 11. kolovoza 2020

Adresa za dopisivanje

Hatice Buyukozer Ozkan

Sveučilište Alanya Alaaddin Keykubat,

Stomatološki fakultet, Zavod za

endodonciju

Konaklı Mah. Mustafa Kemal Blv.

Br: 82 Alanya / Antalya 07400, TURSKA

tel: +905309710252

hatice.ozkan@alanya.edu.tr

hatice.buyukozer@gmail.com

Ključne riječi

sredstva za ispiranje korijenskog kanala; lokalna antimikrobna sredstva; E. faecalis

\section{References}

1. Nair PN, Henry S, Cano V, Vera J. Microbial status of apical root canal system of human mandibular first molars with primary apical periodontitis after “one-visit" endodontic treatment. Oral Surg Oral Med Oral Pathol Oral Radiol Endod. 2005 Feb;99(2):231-52.

2. Mohammadi Z, Abbott PV. The properties and applications of chlorhexidine in endodontics. Int Endod J. 2009 Apr;42(4):288302.

3. Peters LB, Wesselink PR, Buijs JF, van Winkelhoff AJ. Viable bacteria in root dentinal tubules of teeth with apical periodontitis. J Endod. 2001 Feb;27(2):76-81.

4. Stuart CH, Schwartz SA, Beeson TJ, Owatz CB. Enterococcus faecalis: its role in root canal treatment failure and current concepts in retreatment. J Endod. 2006 Feb;32(2):93-8.

5. Sundqvist G. Associations between microbial species in dental root canal infections. Oral microbiol Immunol. 1992 Oct;7(5):25762.

6. Peciuliene V, Balciuniene I, Eriksen HM, Haapasalo M. Isolation of Enterococcus faecalis in previously root-filled canals in a Lithuanian population. J Endod. 2000 Oct;26(10):593-5.

7. Rôças IN, Siqueira JF Jr, Santos KR. Association of Enterococcus faecalis with different forms of periradicular diseases. J Endod. 2004 May;30(5):315-20.

8. Berber VB, Gomes BP, Sena NT, Vianna ME, Ferraz CC, Zaia AA, et al. Efficacy of various concentrations of $\mathrm{NaOCl}$ and instrumentation techniques in reducing Enterococcus faecalis within root canals and dentinal tubules. Int Endod J. 2006 Jan;39(1):10-7.

9. Sen BH, Akdeniz BG, Denizci AA. The effect of ethylenediaminetetraacetic acid on Candida albicans. Oral Surg Oral Med Oral Pathol Oral Radiol Endod. 2000 Nov;90(5):651-5.

10. Gulabivala K, Patel B, Evans G, Ng YL. Effects of mechanical and chemical procedures on root canal surfaces. Endod Topics. 2005;10(1):103-22.

11. Oliveira DP, Barbizam JV, Trope M, Teixeira FB. In vitro antibacterial efficacy of endodontic irrigants against Enterococcus faecalis. Oral Surg, Oral Med, Oral Pathol, Oral Radiol, and Endod. 2007;103(5):702-6.

12. Zehnder M. Root canal irrigants. J Endod. 2006 May;32(5):38998.

13. Shabahang S, Torabinejad M. Effect of MTAD on Enterococcus faecalis-contaminated root canals of extracted human teeth. J Endod. 2003 Sep;29(9):576-9.

14. Zamany A, Spångberg LS. An effective method of inactivating chlorhexidine. Oral Surg, Oral Med, Oral Pathol, Oral Radiol, and Endod. 2002 May;93(5):617-20.

15. Vianna ME, Gomes BP. Efficacy of sodium hypochlorite combined with chlorhexidine against Enterococcus faecalis in vitro. Oral Surg, Oral Med, Oral Pathol, Oral Radiol, and Endod. 2009 Apr;107(4):585-9.

16. Sassone LM, Fidel RA, Murad CF, Fidel SR, Hirata R Jr. Antimicrobial activity of sodium hypochlorite and chlorhexidine by two different tests. Aust Endod J. 2008 Apr;34(1):19-24.

17. Pourhajibagher M, Chiniforush N, Shahabi S, Palizvani M, Bahador A. Antibacterial and antibiofilm efficacy of antimicrobial photodynamic therapy against intracanal Enterococcus faecalis: an in vitro comparative study with traditional endodontic irrigation solutions. J Dent (Tehran). 2018;15(4):197-204.

18. Nowicki JB, Sem DS. An in vitro spectroscopic analysis to determine the chemical composition of the precipitate formed by mixing sodium hypochlorite and chlorhexidine. J Endod. 2011 Jul;37(7):983-8.

19. Basrani BR, Manek S, Sodhi RN, Fillery E, Manzur A. Interaction between sodium hypochlorite and chlorhexidine gluconate. J Endod. 2007 Aug;33(8):966-9.

20. Bui TB, Baumgartner JC, Mitchell JC. Evaluation of the interaction between sodium hypochlorite and chlorhexidine gluconate and its effect on root dentin. J Endod. 2008 Feb;34(2):181-5.

21. Prado M, Santos Junior HM, Rezende CM, Pinto AC, Faria RB, Simao RA, et al. Interactions between irrigants commonly used in endodontic practice: a chemical analysis. J Endod. 2013 Apr;39(4):505-10.

22. Keles A, Ors S, Yilmaz Z. Effect of various solutions on the removal of orange-brown precipitate formed by interaction of sodium hypochlorite and chlorhexidine with or without ultrasonic activation. Niger J Clin Pract. 2020 Mar;23(3):381-5.

23. Liu Y, Guo L, Li Y, Guo X, Wang B, Wu L. In vitro comparison of antimicrobial effectiveness of QMix and other final irrigants in human root canals. Sci Rep. 2015 Dec;5:17823.

24. González-López S, Camejo-Aguilar D, Sanchez-Sanchez P, Bolaños-Carmona V. Effect of CHX on the decalcifying effect of $10 \%$ citric acid, $20 \%$ citric acid, or 17\% EDTA. J Endod. 2006 Aug;32(8):781-4.

25. Rasimick BJ, Nekich M, Hladek MM, Musikant BL, Deutsch AS. Interaction between chlorhexidine digluconate and EDTA. J Endod. 2008 Dec;34(12):1521-3.

26. Anna H, Barnabas P, Zsolt L, Romana Z. Tracking of the degradation process of chlorhexidine digluconate and ethylenediaminetetraacetic acid in the presence of hyper-pure chlorine dioxide in endodontic disinfection. Pharm Biomed Anal. 2019 Feb;164:3604.

27. Buyukozer Ozkan H, Terlemez A, Orhan EO. Proton Nuclear Magnetic Resonance Spectroscopy Analysis of Mixtures of Chlorhexidine with Different Oxidizing Agents Activated by Photon-Induced Photoacoustic Streaming for Root Canal Irrigation. Photobiomodul Photomed Laser Surg. 2020 Jun;38(6):374-379.

28. Torabinejad M, Cho Y, Khademi AA, Bakland LK, Shabahang S. The effect of various concentrations of sodium hypochlorite on the ability of MTAD to remove the smear layer. J Endod. 2003 Apr;29(4):233-9.

29. Siqueira Jr J, Machado A, Silveira R, Lopes H, De Uzeda M. Evaluation of the effectiveness of sodium hypochlorite used with three irrigation methods in the elimination of Enterococcus faecalis from the root canal, in vitro. Int Endod J. 1997 Jul;30(4):279-82.

30. Boutsioukis C, Lambrianidis T, Kastrinakis E, Bekiaroglou P. Measurement of pressure and flow rates during irrigation of a root canal ex vivo with three endodontic needles. Int Endod J. 2007 Jul:40(7):504-13.

31. Shiozawa A. Characterization of reactive oxygen species generated from the mixture of $\mathrm{NaClO}$ and $\mathrm{H} 2 \mathrm{O} 2$ used as root canal irrigants. J Endod. 2000 Jan;26(1):11-5. 
32. Grawehr M, Sener B, Waltimo T, Zehnder M. Interactions of ethylenediamine tetraacetic acid with sodium hypochlorite in aqueous solutions. Int Endod J. 2003 Jun;36(6):411-7.

33. Torabinejad M, Shabahang S, Aprecio RM, Kettering JD. The antimicrobial effect of MTAD: an in vitro investigation. J Endod. 2003 Jun;29(6):400-3.

34. Tay FR, Mazzoni A, Pashley DH, Day TE, Ngoh EC, Breschi L. Potential iatrogenic tetracycline staining of endodontically treated teeth via $\mathrm{NaOCl} / \mathrm{MTAD}$ irrigation: a preliminary report. J Endod. 2006 Apr;32(4):354-8.

35. Tay FR, Hiraishi N, Schuster GS, Pashley DH, Loushine RJ, Ounsi HF, et al. Reduction in antimicrobial substantivity of MTAD after initial sodium hypochlorite irrigation. J Endod. 2006 Oct;32(10):970-5.

36. EPA 2002c. Chlorine Dioxide. U.S. Enviromental Protection Agency Office of Pesticite Programs. April 2002.

37. Eddy RS, Joyce AP, Roberts S, Buxton TB, Liewehr F. An in vitro evaluation of the antibacterial efficacy of chlorine dioxide on $\mathrm{E}$. faecalis in bovine incisors. Endod. 2005 Sep;31(9):672-5.

38. Cobankara FK, Ozkan HB, Terlemez A. Comparison of organic tissue dissolution capacities of sodium hypochlorite and chlorine dioxide. J Endod. 2010 Feb;36(2):272-4.
39. Deka A, Anil TA, Barua P, Paul R. An ex vivo comparative study determining the bactericidal activity of 3 different irrigants against Enterococcus faecalis. Int J Oral Health Dent. 2017 AprJun;3(2):85-8.

40. Singh S, Sinha R, Kar SK, Ather A, Limaye SN. Effect of chlorine dioxide and sodium hypochlorite on the dissolution of human pulp tissue - An in vitro study. Med J Armed Forces India. 2012 Oct;68(4):356-9.

41. Singh S, Arora V, Majithia I, Dhiman RK, Kumar D, Ather A. Comparative evaluation of $15 \%$ ethylenediamine tetra-acetic acid plus cetavlon and $5 \%$ chlorine dioxide in removal of smear layer: A scanning electron microscope study. Contemp Clin Dent. 2013 Jan;4(1):67.

42. Taneja S, Mishra N, Malik S. Comparative evaluation of human pulp tissue dissolution by different concentrations of chlorine dioxide, calcium hypochlorite and sodium hypochlorite: An in vitro study. J Conserv Dent. 2014 Nov;17(6):541-5.

43. Dunavant TR, Regan JD, Glickman GN, Solomon ES, Honeyman AL. Comparative evaluation of endodontic irrigants against Enterococcus faecalis biofilms. J Endod. 2006 Jun;32(6):527-31. 